\title{
Introduction of Microbial Biopolymers in Soil Treatment for Future Environmentally-Friendly and Sustainable Geotechnical Engineering
}

\author{
Ilhan Chang ${ }^{1,+}$, Jooyoung Im ${ }^{2, \dagger}$ and Gye-Chun Cho ${ }^{2, *, \dagger}$ \\ 1 Geotechnical Engineering Research Institute, Korea Institute of Civil Engineering and Building \\ Technology (KICT), Goyang 10223, Korea; ilhanchang@kict.re.kr \\ 2 Department of Civil and Environmental Engineering, Korea Advanced Institute of Science and \\ Technology (KAIST), Daejeon 34141, Korea; jooyoungim@kaist.ac.kr \\ * Correspondence: gyechun@kaist.edu; Tel.: +82-42-350-3622; Fax: +82-42-350-7210 \\ + These authors contributed equally to this work.
}

Academic Editor: Michael A. Fullen

Received: 24 November 2015; Accepted: 3 March 2016; Published: 10 March 2016

\begin{abstract}
Soil treatment and improvement is commonly performed in the field of geotechnical engineering. Methods and materials to achieve this such as soil stabilization and mixing with cementitious binders have been utilized in engineered soil applications since the beginning of human civilization. Demand for environment-friendly and sustainable alternatives is currently rising. Since cement, the most commonly applied and effective soil treatment material, is responsible for heavy greenhouse gas emissions, alternatives such as geosynthetics, chemical polymers, geopolymers, microbial induction, and biopolymers are being actively studied. This study provides an overall review of the recent applications of biopolymers in geotechnical engineering. Biopolymers are microbially induced polymers that are high-tensile, innocuous, and eco-friendly. Soil-biopolymer interactions and related soil strengthening mechanisms are discussed in the context of recent experimental and microscopic studies. In addition, the economic feasibility of biopolymer implementation in the field is analyzed in comparison to ordinary cement, from environmental perspectives. Findings from this study demonstrate that biopolymers have strong potential to replace cement as a soil treatment material within the context of environment-friendly construction and development. Moreover, continuing research is suggested to ensure performance in terms of practical implementation, reliability, and durability of in situ biopolymer applications for geotechnical engineering purposes.
\end{abstract}

Keywords: soil treatment; engineered soil; geotechnical engineering; biopolymer; environmentally-friendly; $\mathrm{CO}_{2}$ emission; soil strengthening

\section{Introduction}

Geotechnical engineering, especially the treatment and usage of soil (or earth) in construction, is a long-standing technical field, dating to the beginning of human civilization. In ancient Mesopotamia and Babylonia, mud was used as a common construction material for various forms of bricks (i.e., sun-dried and kiln-fired) to create the architecture of the city. Sumerians widely used bitumen as a binder to enhance the strength and durability of earth walls [1]. In ancient Egypt, earth engineering methods were developed to create river embankments to control the annual flooding of the Nile river [2]. Engineers in ancient China used a sticky rice mortar that contained amylopectin as a construction binder for the Great Wall [3].

As civilization has advanced, the durability and strength of construction materials has improved as well. The discovery of natural pozzolan materials such as volcanic ash improved construction 
materials, including the well-known concrete of ancient Rome. The representative formula for Roman concrete was a mixture of volcanic dust with a binder such as gypsum or lime, with added aggregates, and it was used to create highly durable structures including arches and domes [4]. After the Industrial Revolution, ordinary cement (i.e., Portland cement) became the most widely used construction and building material, not only for structural purposes, but also for soil stabilization and strengthening purposes (Figure 1).

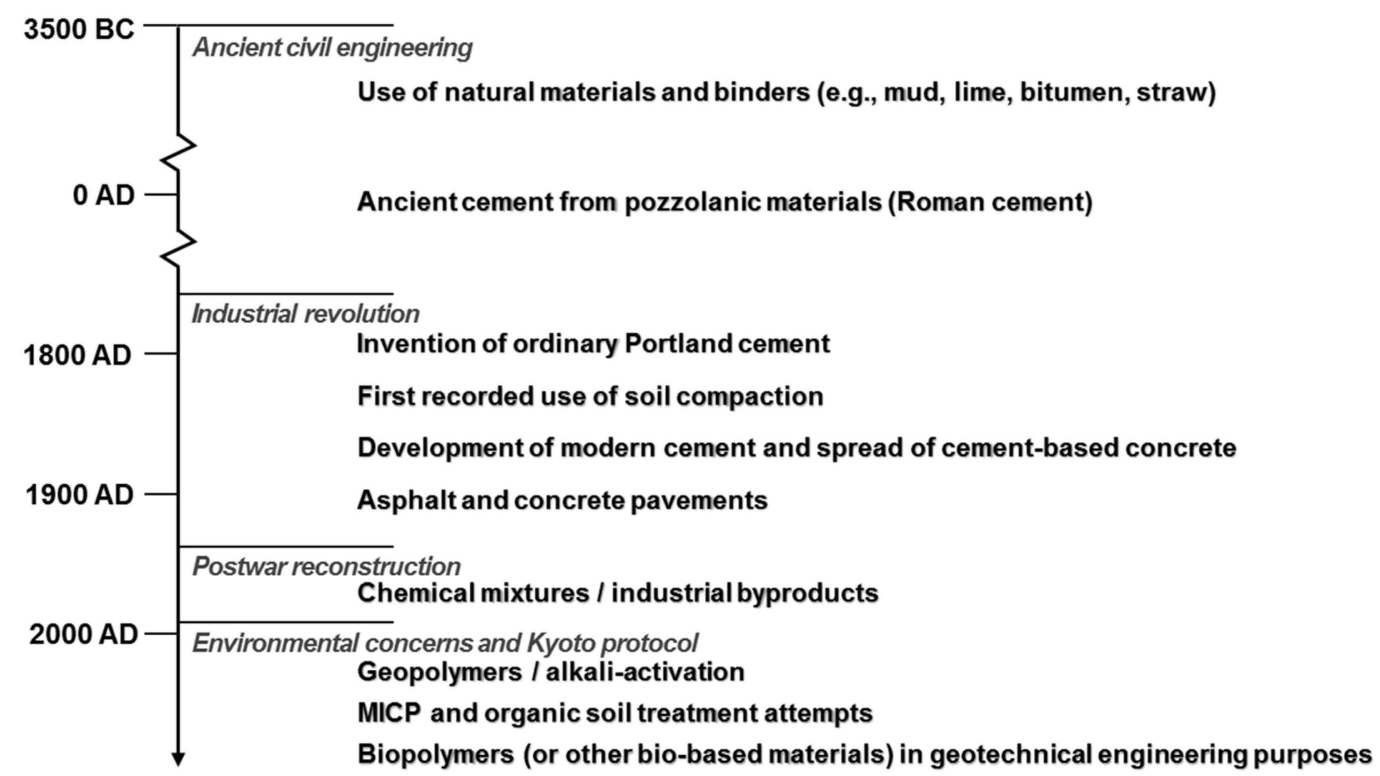

Figure 1. Advancement of engineered soil materials in geotechnical engineering.

The main purpose of soil treatment and improvement (i.e., engineered soil) is to enhance the engineering characteristics of a particular soil, including its strength (i.e., resistance), hydraulic conductivity, and durability against repeating wetting and drying, as well as for environmental revitalization [5]. Two primary methods are conventionally applied to produce engineered soil: mechanical improvement and chemical treatment. Mechanical improvement is a process of reinforcing the strength of the soil through physical processes such as compaction, drainage, external loading (e.g., surcharge), consolidation, or other means. Chemical treatment involves chemical reactions such as hydration or pozzolanic reactions inside the soil to create artificial binding, such as the use of calcium silicate hydrate (C-S-H) between soil particles [5].

As an alternative to such traditional soil treatment and improvement techniques, biological approaches are now being actively investigated in the field of geotechnical engineering, including microbe injection and byproduct precipitation. In particular, microbial induced polymers-or biopolymers-have been introduced as a new type of construction binder, especially for soil treatment and improvement.

To date, most studies on these applications of biopolymers have been experimental efforts that have produced preliminary findings and analyses, and the number of theoretical explanations and case studies of practical implementation in the literature are still limited. In response, this paper provides a detailed review of biopolymer applications in geotechnical engineering including the most recent studies. In this review, strengthening mechanisms between typical biopolymers and soils based on microscopic inter-particle interactions are summarized. The advantages and disadvantages of biopolymer applications are compared with those of existing soil engineering methods. Finally, the potential for practical implementation is evaluated via an economic feasibility analysis, including environment-friendly considerations. 


\section{Environmental Concerns Affecting Soil Treatment in Geotechnical Engineering}

\section{1. $\mathrm{CO}_{2}$ Emissions related to Cement Usage in Civil and Geotechnical Engineering}

Ordinary Portland cement currently dominates the field of materials used for construction and civil engineering purposes: 5245 million tons of hydraulic (i.e., ordinary Portland) cement were produced worldwide in 2012 [6]. Portland cement has multiple engineering benefits, such as high strength and durability, workability, and hydraulicity, as well as low cost (60 100 USD/ton, in developed countries), and these factors have contributed to its widespread use in various applications for ground improvement, concrete structures, and pavement in civil and construction engineering [7].

In geotechnical engineering projects, cement has been used in numerous formats, including deep cement mixing (DCM), grouting, soil nails, and soil stabilization, and is now the most favored material for engineered soil. However, despite cement's benefits and its numerous applications, the overdependence on and overuse of cement has given rise to a number of environmental concerns.

In the production of cement, the calcination of calcium carbonate (i.e., $5 \mathrm{CaCO}_{3}+2 \mathrm{SiO}_{2} \rightarrow$ $3 \mathrm{CaO} \cdot \mathrm{SiO}_{2}+2 \mathrm{CaO} \cdot \mathrm{SiO}_{2}+5 \mathrm{CO}_{2}$ ) liberates 0.55 tons of $\mathrm{CO}_{2}$ per 1 ton of Portland cement, which is then emitted to the atmosphere. In addition, approximately 0.4 tons of $\mathrm{CO}_{2}$ are emitted due to the burning of carbon fuel during the production of 1 ton of cement, since calcination requires heat as high as $1450^{\circ} \mathrm{C}$. The total amount of $\mathrm{CO}_{2}$ emitted per each ton of cement produced is 0.95 tons [8].

In 1995, for example, $1453 \mathrm{M}$-tons of cement were produced worldwide, accounting for approximately $5 \%$ of the global annual $\mathrm{CO}_{2}$ emissions [9]. By 2003, the amount of $\mathrm{CO}_{2}$ emissions from cement production had increased to $7 \%$ of the global $\mathrm{CO}_{2}$ emissions [10]. This means that the rate of $\mathrm{CO}_{2}$ emissions related to cement production (Figure 2a) has doubled during the past 30 years, from $4.2 \%$ in 1980 to $9.0 \%$ in 2012. Moreover, the annual growth rate of cement related $\mathrm{CO}_{2}$ emission continues to increase annually-it reached $10 \%$ in 2010-in spite of global efforts to reduce $\mathrm{CO}_{2}$ emissions by limiting its annual growth rate to less than $3 \%$ (Figure $2 \mathrm{~b}$ ).

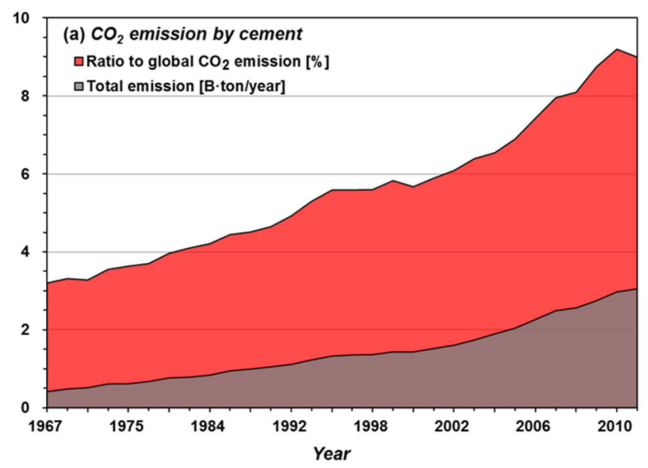

(a)

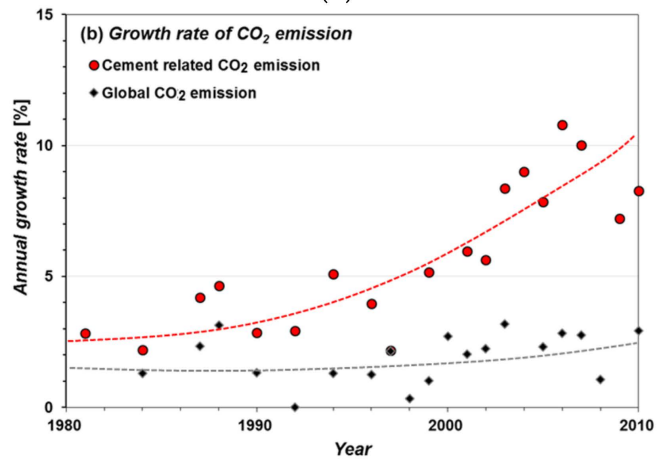

(b)

Figure 2. $\mathrm{CO}_{2}$ emissions of cement through the years (after [11] (a) and [12] (b)). 
$\mathrm{CO}_{2}$ emissions related to the usage of cement in geotechnical applications (e.g., mixing, grouting, soil stabilization) amount to approximately $2 \%$ of the total $\mathrm{CO}_{2}$ emissions by cement (i.e., $3.05 \mathrm{~B}$. tons in 2011) [11,13]. Thus, replacing $10 \%$ of cement usage with low-carbon materials in geotechnical engineering implementations leads to a reduction of $6.1 \mathrm{M}$ - tons of $\mathrm{CO}_{2}$, which is close to $10 \%$ of the annual $\mathrm{CO}_{2}$ emissions from Austria (66.68 M-tons) in 2012 [14].

\subsection{Other Environmental Concerns from the Use of Cement}

The presence of cement inside soil (e.g., mixed into soil) quickly raises the $\mathrm{pH}$ of the soil up to 12-13, due to the release of alkaline hydroxide (OH-) ions as a byproduct of hydration [15]. This increase in $\mathrm{pH}$ can affect biological organisms, and could thereby have detrimental effects [16].

The widespread use of cement-based construction also gives rise to several related issues in the urban environment, such as an increase of urban water runoff, heat islands, and prevention of vegetation growth. Moreover, as the hydration reaction of cement is irreversible, it is difficult to return soil-cement mixtures to their original state (i.e., untreated soil), and furthermore demolition problems arise [17].

Urban runoff is known to be amplified due to the massive use of impervious cement-based concrete with increasing urbanization. The absence of ground infiltration and severe surface runoff can produce floods, and they are strongly related to economic and ecological losses such as residential or infrastructural damage $[18,19]$. Moreover, surface runoff also degrades overall water quality by flushing various pollutants and contaminants into waterways from urban sources [20,21].

The urban heat island effect is mainly caused by concrete or asphalt materials, whose specific heats are lower than that of soil [22]. Urban heat islands can have a number of environmental impacts such as affecting local wind patterns and humidity and causing the development of urban smog and localized heavy precipitation [23,24].

Moreover, the presence of cementitious covers also prevents the growth of surface vegetation. Vegetation such as trees and grass can lower the surrounding temperature via evapotranspiration and by providing shade. Thus, vegetation can reduce peak summer temperatures in urban areas by $1-5{ }^{\circ} \mathrm{C}$, and can also be used to mitigate urban heat islands [25]. In addition, the presence of vegetation has other benefits, including increasing the efficiency of cooling systems, enhancing rainwater management and water quality by absorbing and filtering precipitation, and improving air quality [26].

Cement demolition waste and its management by disposal or recycling has become a significant environmental concern at the end of the life cycle of cement-based concrete structures [27]. Moreover, cement used for geotechnical purposes such as deep mixing or grouting is difficult to remove from the ground.

Concrete dust can be released into the air through various pathways such as concrete structure demolition or natural disasters (e.g., earthquakes), and can induce lung diseases [28]. For example, high concentrations of concrete dust, $150 \mu \mathrm{g} / \mathrm{m}^{3}$, were monitored after the Great Hanshin earthquake in Japan in 2015, where the alkaline component of the concrete dust in the air was equivalent to an amount sufficient to neutralize the annual acid rainfall in Japan [29].

\subsection{Soil Treatment Methods with Environmentally-Friendly Aspects}

While the use of cement creates a number of environmental problems, as mentioned in the previous section, the construction industry also accounts for approximately $40 \%$ of global energy consumption [30]. In response, environmental-friendly and sustainable approaches involving the use of alternative materials, including geosynthetics, chemical polymers, geopolymers, or biological treatment have recently emerged in the field of geotechnical engineering.

Geosynthetics are artificial polymeric products, including geotextiles, geogrids, geonets, geomembranes, geosynthetic clay liners, geofoam, geocells, and geocomposites, which are implanted into the soil to strengthen or enhance the soil's geotechnical engineering properties. Geosynthetics have high tensile strength, flexibility, and impervious characteristics, and are therefore generally used for soil 
separation, filtering, reinforcement, and drainage purposes across a large range of applications [31-33]. While such materials can provide higher strength, specifically tensile strength, the strengthening is almost completely dependent on the material itself and not the soil, making them undesirable for various engineering practices.

In the late 20th century, geotechnical engineers began introducing chemically synthesized polymers as soil conditioners to replace the use of conventional binders, such as lime and cement, for geotechnical engineering and agricultural purposes. Polyacrylamide (PAM) [34] is a simple linear- or cross-linked polymer synthesized by acrylamide (i.e., $\mathrm{CH}_{2} \mathrm{CHCONH}_{2}$ ) subunits, which are non-toxic and hydrophilic [35]. Anionic polyacrylamide (PAM) has negative charge density and induces electrostatic bonding with clay particles [36,37], which results in reduced soil erosion and runoff control [38]. PAM consequently has been used in various fields such as agriculture, construction, and military applications (e.g., temporary helicopter landing fields) as a soil erosion reduction agent $[38,39]$. Sodium silicate $\left(\mathrm{Na}_{2}\left(\mathrm{SiO}_{2}\right)_{\mathrm{n}} \mathrm{O}\right)$ and other chemicals, including acrylics, lignosulfonates, and phenolasts, have been widely implemented in soil grouting practices, especially for sandy soils. However, chemically synthesized polymers and solutions have raised concerns about toxicity and water pollution problems [40], and this has restricted the usage of chemical solutions near water conservation regions in particular.

Meanwhile, electroosmotic chemical treatment (ECT) has been attempted in several studies to improve the strength of soft soils [41,42]. However, the ECT method requires massive injection of chemical solutions to produce an increase in osmotic pressure, and has not yet been accepted for practical implementation [43].

Geopolymers are polymers synthesized from either organic or inorganic, such as silicon-based, origins [44,45]. The geopolymerization process involves initial mixing in an alkaline solution, which dissolves silicon and aluminum ions (i.e., alkali-activation) from soil or industrial byproducts such as fly ash or blast furnace slag. Hydroxyl ions $\left(2 \mathrm{OH}^{-}\right)$remaining in the alkaline solution then react to form one free water molecule $\left(\mathrm{H}_{2} \mathrm{O}\right)$ and an oxide ion $\left(\mathrm{O}^{2-}\right)$ [46]. The released oxygens then form monomers with the dissolved silicon and aluminum ions, which undergo condensation. Geopolymers require isolated heating (above $60^{\circ} \mathrm{C}$ ) for proper geopolymerization (hardening) [47,48], which can limit site application for geotechnical engineering purposes. Studies have shown that geopolymers are highly susceptible to water and show significant degradation in strength when saturated in water, especially in acid solutions, due to depolymerization of the aluminosilicate polymers and removal of silicic acid [49].

\section{Application of Biological Approaches to Geotechnical Engineering}

\subsection{Attempts with Bio-Mineralization}

Since the beginning of the 21st century, researchers have been seeking more biogenic alternatives to existing strengthening agents. Recently, environment-friendly approaches that involve the use of biological materials such as microbes and enzymes have emerged in attempts to improve the mechanical properties of soil with a remarkably smaller carbon footprint compared to the use of cement in geotechnical engineering practices. The most common approach is bio-mineralization, which entails mineral precipitation in soil pores via biological organisms [50]. Another approach, based on biofilm formation, starts with a weak attraction force between microorganisms that later develops into a larger attachment that is irreversible [51].

Among bio-mineralization strategies, the most recognized soil treatment method is microbial induced calcite precipitation (MICP). MICP employs microorganisms including Sporosarcina pasteurii and Bacillus pasteurii to precipitate calcium carbonate crystals in soil voids and thereby provide inter-particle bonding $[52,53]$. MICP occurs through urea hydrolysis, which primes the soil for calcium carbonate precipitation when calcium is present [54]. Ureolytic bacteria are used to convert urea to ammonium and carbonate. Calcium carbonate precipitates are then formed from the carbonate and 
calcium ions [55]. The calcium carbonate precipitates bind with the soil grains to increase the strength and stiffness of the soil [56].

Several studies have been performed to increase the strength and stiffness of soils using urease positive microorganisms [53,57]. In these studies, the microorganism Sporosarcina pasteurii was injected directly into the soil to allow for calcite precipitation by the microorganisms themselves.

The use of urea, $\mathrm{CaCl}_{2}$, and urease leads to the precipitation of calcite through enzymatic processes without microbial activities, which is suitable for soil strengthening and increasing stiffness [58]. MICP has also been found to be applicable in various other fields, including the remediation of heavy metals [59], $\mathrm{CO}_{2}$ sequestration [60], and the repair of concrete [61,62].

However, MICP has several shortcomings in terms of field implementation. MICP is most applicable to coarse sediments, and accompanies difficulties when used with fine grained soils due to infiltration problems: the pore sizes of fine grained sediments provide an unsuitable environment for bacteria growth [63]. Moreover, the transport, cultivation, and fixation performance of bacteria is not consistent. Thus, recent studies have adopted the use of urease enzyme instead of using bacteria to promote the hydrolysis of urea, for the chemical precipitation of calcite [64]. Furthermore, the use of MICP results in a highly concentrated ammonium chloride byproduct, which needs to be removed and treated, generally in the form of soil flushing [65].

Even though the limitations of MICP are problematic, the bio-soil method has been shown to have several promising features, including high strengthening, low environmental impact, self-proliferation, and biodegradation. A number of researchers have thus focused on the direct use of biogenic excrement (i.e., biopolymers) instead of attempting to cultivate the microorganisms in the soil.

\subsection{Biopolymers: Definition and Usage}

Biopolymers are organic polymers that are synthesized by biological organisms. They consist of monomeric units that are bonded into larger formations. The use of biopolymers is, in fact, not an entirely new development in geotechnical engineering. Organic polymers such as natural bitumen, straw, and sticky rice have been used in ancient civilizations and can also be classified as biopolymers in a broad sense. In ancient Chinese civilization, sticky rice mortar was used as a binder. Sticky rice soup mixed with Actinidia chinensis cane juice, lime, loess, and river sand produced a mortar with good strength, high toughness, and water resistance [66].

Among the three typical types of biopolymers-polynucleotides (e.g., RNA and DNA), polypeptides (e.g., composed of amino acids), and polysaccharides-polysaccharides have been the most commonly applied contemporary biopolymer type in various practices $[67,68]$.

Polysaccharides are polymeric carbohydrate chains composed of monosaccharide units. Polysaccharides are widely found in nature because they are employed in key biological roles, as substances forming skeletal structures, assimilative reserve substances, and water binding substances [69]. The properties of polysaccharides have led to their widespread use as thickening agents, stabilizers, sweeteners, and gel forming agents in the fields of food production, agriculture, cosmetics, medical treatment, and pharmaceuticals [70-72].

\subsection{Biopolymers in Geotechnical Engineering}

Biopolymers mixed with soil, such as sticky rice mortar, promote strengthening of the soil, including increased cohesion and strength, resistance to erosion, reduced permeability, etc., by acting as a binder. The direct use of biopolymers in soil has several benefits over pre-existing biological soil treatment methods [73]. The direct use of exo-cultivated biopolymers for soil treatment overcomes several shortcomings of other approaches (e.g., microbe injection) such as the need for microbial and nutrient injection, time for cultivation and excrement precipitation, and inappropriateness with clayey soils [74]. Moreover, since biopolymers are readily found in nature and many are known to be harmless and edible, biopolymers can be considered eco-friendly substitutes for soil treatment. Several polysaccharide group biopolymers recently have been examined for use in geotechnical engineering. 
The characteristics of common biopolymers are summarized in Table 1, and the following sections review notable case studies in geotechnical engineering.

Table 1. Characteristics of common biopolymers (after [35,75-81]).

\begin{tabular}{cll}
\hline Biopolymer & \multicolumn{1}{c}{ Composition } & \multicolumn{1}{c}{ Characteristics } \\
\hline Cellulose & $\beta$ - $(1 \rightarrow 4)$-D-glucose linkages & $\begin{array}{l}\text { - Hydrophilic } \\
\text { - Properties depend on the chain length }\end{array}$ \\
\hline Starch & $\begin{array}{l}\text { D-glucose residues linked by } \\
\alpha-(1,4) \text { glucosidic bonds }\end{array}$ & $\begin{array}{l}\text { - Soluble in heated water } \\
\text { - Viscous, gelatinization }\end{array}$ \\
\hline \multirow{2}{*}{ Chitosan } & $P$ - $(1,4)$-2-amino-2-deoxy-D-glucose & $\begin{array}{l}\text { - Soluble in acidic solvents } \\
\text { - Bioadhesive for (-) charged surfaces }\end{array}$ \\
\hline Xanthan & $\mathrm{C}_{35} \mathrm{H}_{49} \mathrm{O}_{29}$ & - High viscous rheology \\
\hline Curdlan & $\left(\mathrm{C}_{6} \mathrm{H}_{10} \mathrm{O}_{5}\right)_{\mathrm{n}}$ & - Gel formation via heating in aqueous solutions \\
\hline \multirow{2}{*}{ Beta-Glucan } & $\begin{array}{l}\mathrm{D} \text {-glucose monomers linked by } \\
\beta \text {-glycosidic bonds }\end{array}$ & $\begin{array}{l}\text { - Capable of immune activation in humans } \\
\text { - Cholesterol absorption capabilities }\end{array}$ \\
\hline \multirow{2}{*}{ Polyacrylamide } & $\left(\mathrm{C}_{3} \mathrm{H}_{5} \mathrm{NO}\right)_{\mathrm{n}}$ & $\begin{array}{l}\text { - Water absorbent, gel formation } \\
\text { - Thickener }\end{array}$ \\
\hline
\end{tabular}

\subsubsection{Cellulose and Starch}

Cellulose $\left(\mathrm{C}_{6} \mathrm{H}_{10} \mathrm{O}_{5}\right)_{n}$ is abundantly present in nature. It consists of $\beta-(1 \rightarrow 4)$-D-glucose linkages, and is the main component in the cell walls of plants, and has the longest history of utilization in engineering (e.g., straw fibers in adobe bricks). Its most notable current uses are in the food industry where it is used for packaging materials and for thickeners or stabilizers for food [82]. Cellulose has various potential uses in geotechnical engineering applications due to its gelation properties, which can be exploited to produce thickeners and stabilizing agents [75]. Natural cellulose-group fibers significantly increase the tensile and flexural strength of soils [83,84]. Furthermore, cellulose has been used in open graded friction coarse (OGFC) pavement. OGFC consists of single size coarse aggregates with large voids, resulting in high asphalt content, and cellulose improves its performance by limiting coarse aggregate pop-out and reflective cracking [80]. In addition, organic compost containing high cellulose content has been reported to induce higher soil aggregate stability by increasing water repellency [85].

Starch is a polysaccharide that consists of D-glucose residues linked by $\alpha-(1,4)$ glucosidic bonds [86]. It can be naturally found in a variety of plants, such as maize, rice, wheat, potatoes, and cassava [87], and it has been applied in numerous areas outside of food and agriculture. The major area of starch application in geotechnical engineering has been in adhesives for drilling fluids [88]. The use of starch in thermoplastic materials provides two major benefits: (i) it allows for continuously tunable processed materials; and (ii) because it is an abundant and inexpensive raw material, large scale production can be economically achieved [89].

\subsubsection{Chitosan}

Chitosan (P-(1,4)-2-amino-2-deoxy-D-glucose) is the degraded form of chitin, found in the exoskeletons of crustaceans and the cell walls of fungi. It is typically extracted by alkali sodium hydroxide treatment. This hydrophilic biopolymer has been used in a variety of applications. As a biorenewable, biocompatible, biodegradable, and biofunctional biopolymer, chitosan has been used and researched in the fields of food/nutrition, material science, medical science, microbiology, and immunology, as well as other fields such as agriculture, wastewater treatment, and degradation products $[81,90,91]$. In geotechnical and geoenvironmental contexts, chitosan has been shown to be capable of decontaminating groundwater containing contaminants such as copper (II) $\left(\mathrm{Cu}^{2+}\right)$ and phosphorus (P-) $[92,93]$. Chitosan coated sand particles have practical implications in filters for 
remediation of contaminated groundwater [81] and can create a suitable plugging effect by reducing the hydraulic conductivity of sandy soils [94].

\subsubsection{Curdlan}

Curdlan is a high molecular weight linear $\beta$-1,3-glucan biopolymer produced by pathogenic bacteria (e.g., Agrobacterium biobar, Alcaligenes faecalis) that forms an elastic gel when heated in an aqueous solution [79]. Curdlan has been used as an additive in concrete mixtures as a superplasticizer to improve workability and prevent cement-aggregate separation [95]. From a geotechnical perspective, curdlan has been suggested for use in grouting due to its large scale soil clogging potential [96].

\subsubsection{Beta-Glucan}

Beta-glucans are biopolymers that consist of D-glucose monomers that are linked by glycosidic bonds [97]. $\beta$-glucan is naturally found in various formations, such as in cellulose, bran, and the cell walls of yeast, fungi, and bacteria [77].

A small amount $(0.25 \%)$ of beta-glucan biopolymer (i.e., mass ratio to soil) in soil provides a compressive strength value of $2650 \mathrm{kPa}$, comparable to that of a $10 \%$ cement mix (2170 $\mathrm{kPa})$, while $0.5 \%$ beta-glucan mixing yields soil strength up to $4310 \mathrm{kPa}$ [98]. From a geotechnical perspective, the presence of beta-glucan in soil increases the Atterberg limit values as well as shear stiffness $(G)$, while it seems to have minor or even no effects on the constrained modulus $(M)$ of soil [99]. A recent study showed that beta-glucan treatment promotes vegetation growth in treated soils as well as high strength, and in particular it promoted vegetation growth on barren soil, indicating its potential for use as a countermeasure for desertification [100].

\subsubsection{Xanthan Gum}

Xanthan gum is a polysaccharide that is made by the Xanthomonas campestris bacterium, and is generally used as a viscosity thickener due to its hydrocolloid rheology [76]. Xanthan gum has been introduced to geotechnical engineering to reduce the hydraulic conductivity of silty sand via pore filling $[94,101]$ as well as to increase the undrained shear strength of soil by increasing the liquid limit [102]. Another recent study has studied possibilities for using xanthan gum as a soil strengthener, and showed that xanthan gum preferentially forms firm xanthan gum-clayey soil matrices via hydrogen bonding [103].

\subsubsection{Agar Gum}

Agar gum is a polysaccharide that is composed of linked galactose molecules, and is extracted from rhodophyceae [96]. Agar gum has rheological properties that make it useful as a thickener, stabilizer, and emulsifier. Moreover, agar gum has a thermogelation property that allows the formation of strong gels when cooled back to room temperature after being dissolved in boiling water [104]. Agar gum effectively improves the strength of sand (especially cohesion) without environmental risks [105] Recently, researchers attempted to use agar gum to enhance the strength of soils, showing that the use of 3\% (to soil mass) thermal treated agar gum enhanced the unconfined compressive strength of soil up to $10 \mathrm{MPa}$ under a dried condition [106].

\subsubsection{Gellan Gum}

Gellan gum is a high molecular weight polysaccharide fermented from Spingomonas elodea (formerly known as Pseudomonas elodea) microbes [107]. Gellan gum is usually used as a substitute for agar gum, with which it shares many properties, including thermogelation properties [108,109]. Gellan gum shows great promise for application as an engineered soil material due to its high strengthening effect [110]. A recent study showed that $3 \%$ of gellan gum dispersed within a clayey soil exhibited a maximum unconfined compressive strength of $12.6 \mathrm{MPa}$ [106]. Although gellan gum has 
a similar gelation rheology and strengthening effect to agar gum, gellan gum is preferred for future mass commercialization because it can be easily produced via microbial fermentation, whereas agar gum has to be extracted from seaweed (i.e., algae).

\section{Mechanisms of Soil-Biopolymer Interaction}

\subsection{How Biopolymers Strengthen Soil}

A small quantity (i.e., $0.5 \%-1 \%$ to the soil weight) of biopolymer in soil can produce significant strengthening effects (Figure 3). In general, biopolymers have high specific surfaces with electrical charges, which enable direct interactions between the biopolymers and fine soil particles, thereby providing firm biopolymer-soil matrices with high strength. SEM images of sand-clay-biopolymer mixtures show that biopolymers directly bond with kaolinite particles, producing accumulated face-to-face clay layers, while sand surfaces remain clean or only film-type coats form around particles (Figure 4). Thus, the strengthening is maximized in the presence of clayey particles due to the hydrogen and ionic bonding between the biopolymers and clay particles, which have electrical charges [103,106].
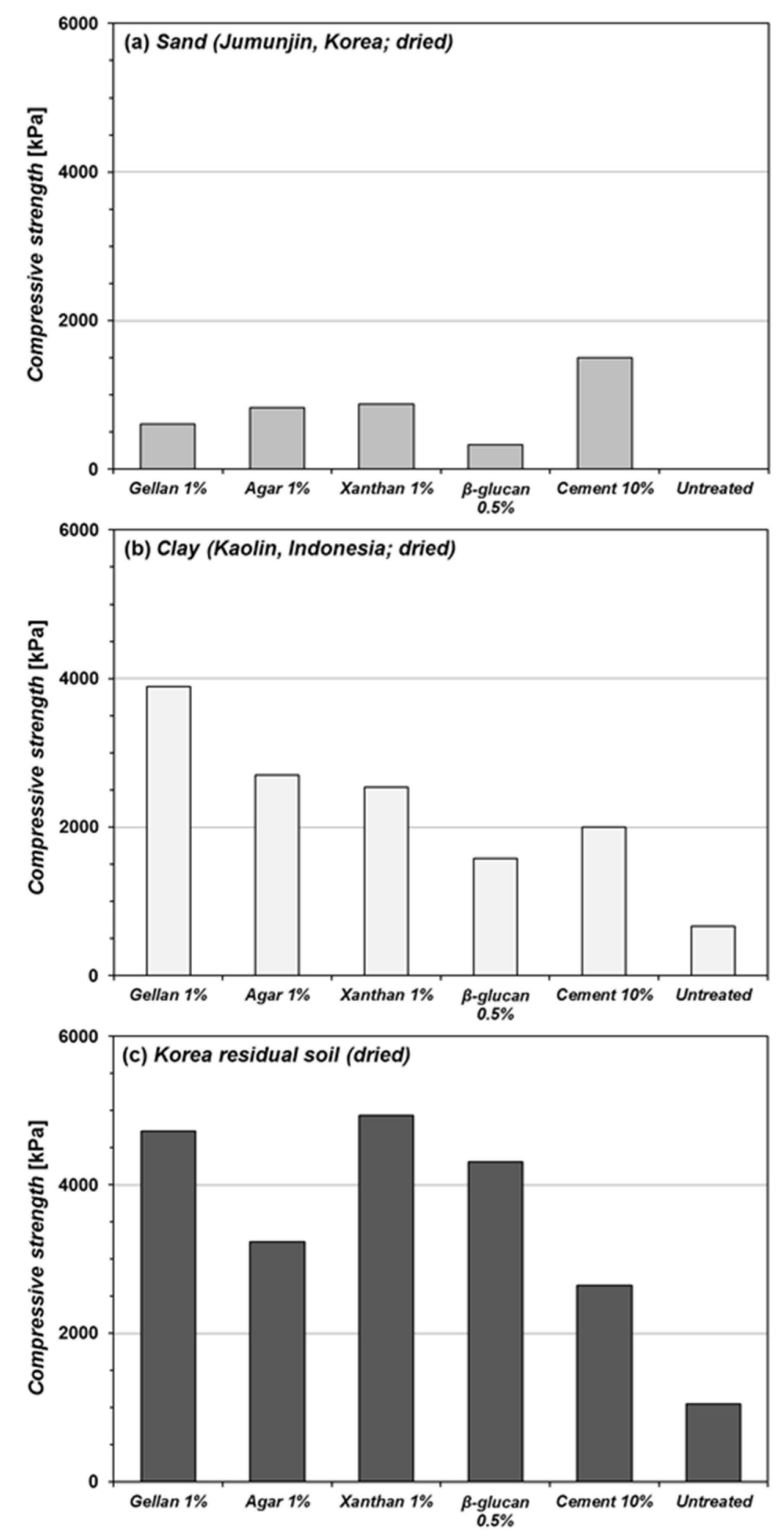

Figure 3. Compressive strengths of biopolymer-treated soils. 


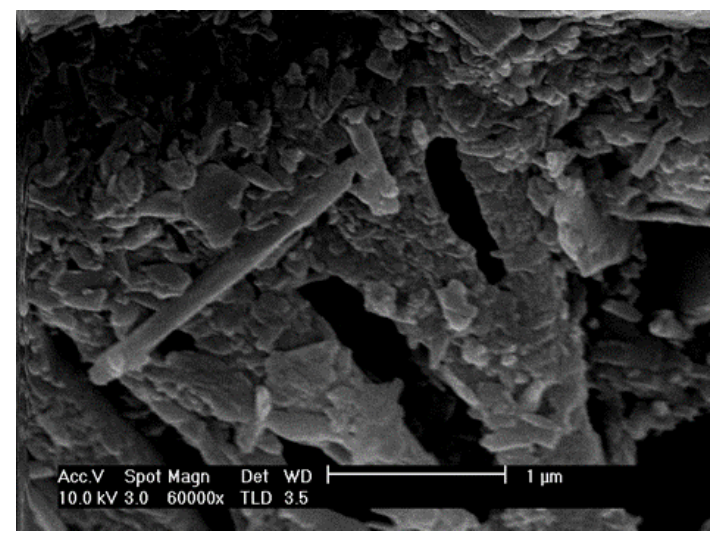

(a)

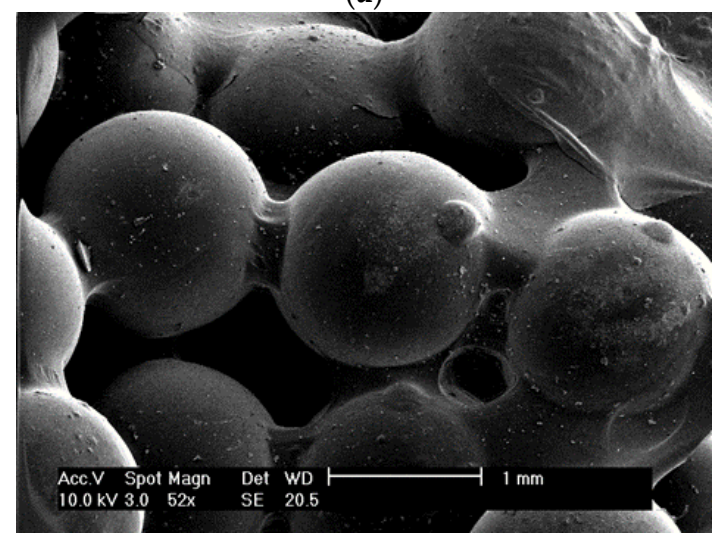

(b)

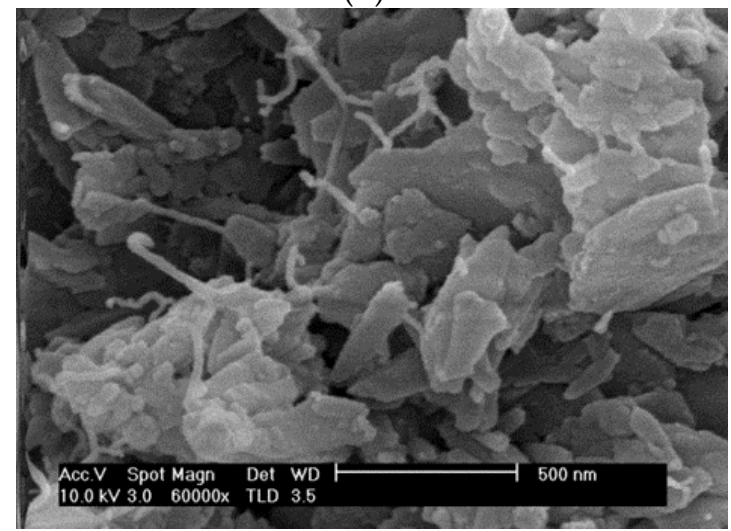

(c)

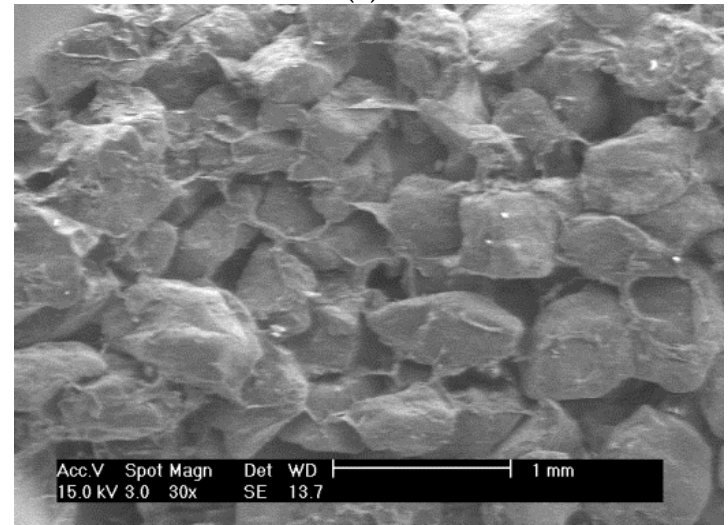

(d)

Figure 4. Cont. 


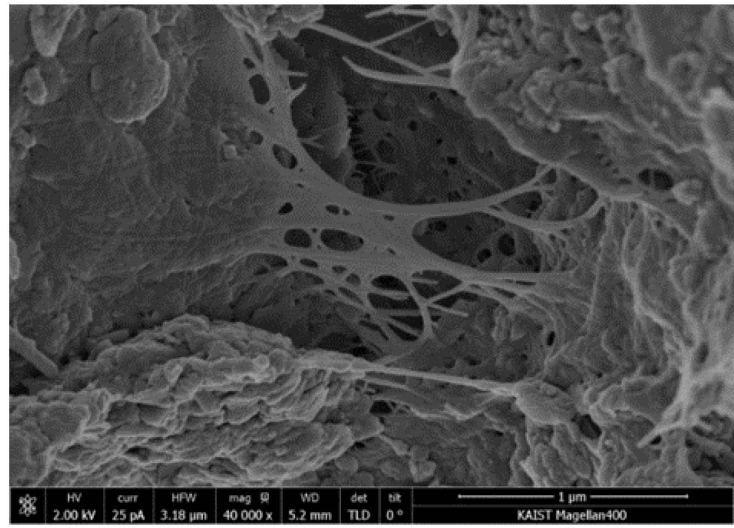

(e)

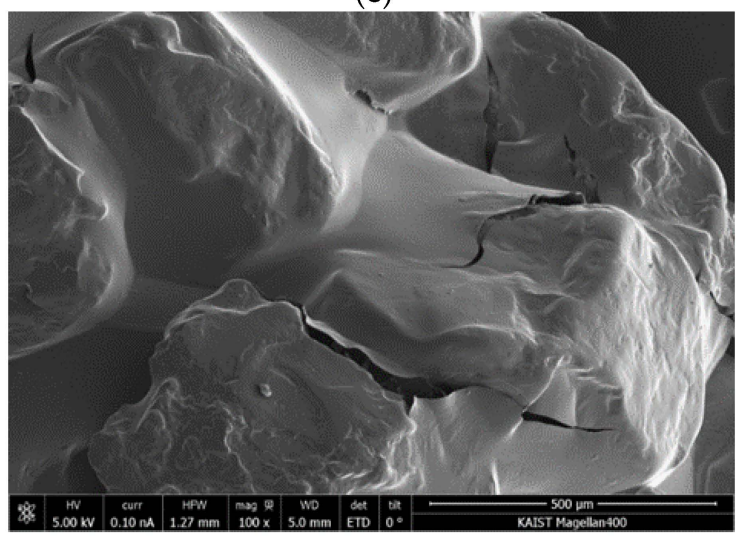

(f)

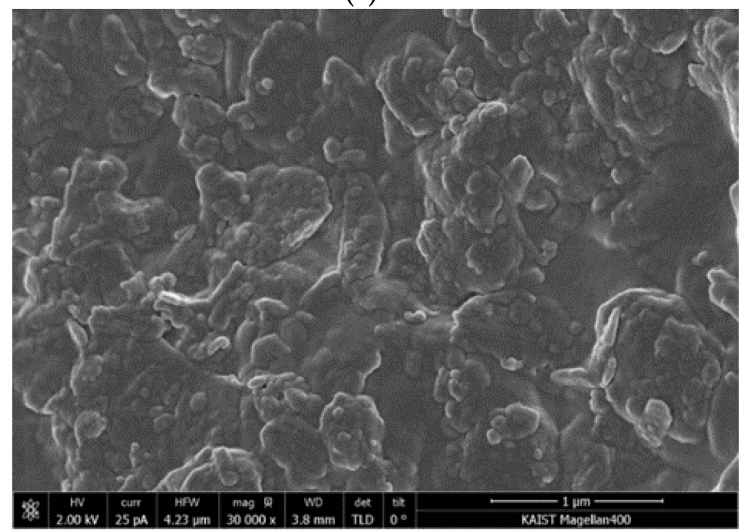

(g)

Figure 4. SEM images of biopolymer-soil mixtures: (a) Beta-glucan and Korea residual soil; (b) Beta-glucan and glassbeads; (c) Xanthan gum and kaolin clay; (d) Xanthan gum and sand (Jumunjin, Korea); (e) Gellan gum and kaolin clay; (f) Gellan gum and sand (Jumunjin, Korea); and (g) Agar gum and kaolin clay (images from $[98,103,106])$.

However, this does not mean that biopolymers have a negligible impact in terms of their use with sand particles, because well-graded soil with coarse particles treated with biopolymers shows higher strength than that obtained with pure clay, such as kaolinite [103].

Figure 5 shows the inter-particle cohesion and friction angle variation of $1 \%$ gellan gum biopolymer mixed soils, evaluated via direct shear tests. Although the unconfined compressive strength (Figure 3) and cohesion of biopolymer mixed clay is much higher than that produced in pure sand, the friction characteristics of sandy soils (i.e., sand-clay mixtures) are more appropriate for practical applications than those of pure clay. Thus, the strengthening mechanism of biopolymers 
in ordinary soils (i.e., those containing both sand and clay) is believed to be a combination of the formation of biopolymer-clayey soil matrices (i.e., cohesion enhancement) and friction improvement via coarse particles acting as aggregates (Figure 6). Inter-particle cohesion enhancement depends on the strength of the biopolymer-clayey soil matrices, which is higher with lower water content. The friction angles of the soil increase with biopolymer treatment due to improved particle contact. The stiffer dried gels add a substantial amount of strength with a small increase in the contact radius, especially at lower water content, as opposed to the softer wet gels, which exhibit almost no increase in strength with a small increase in the contact radius.

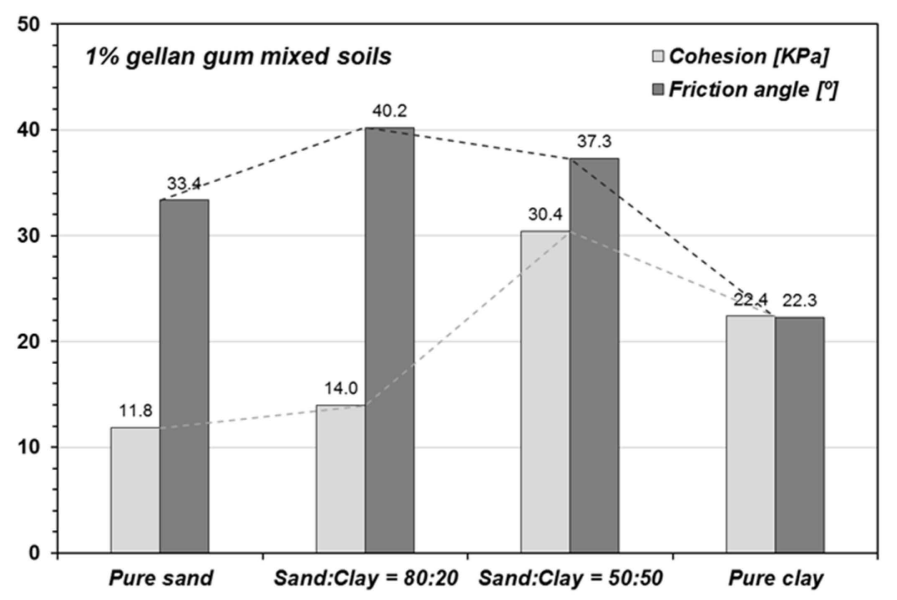

Figure 5. Direct shear test result of 1\% gellan gum biopolymer mixed soils.

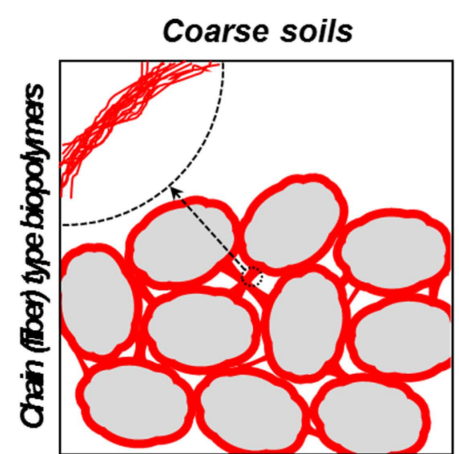

(a)

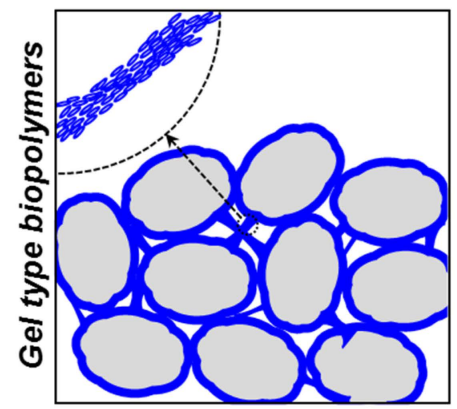

(b)

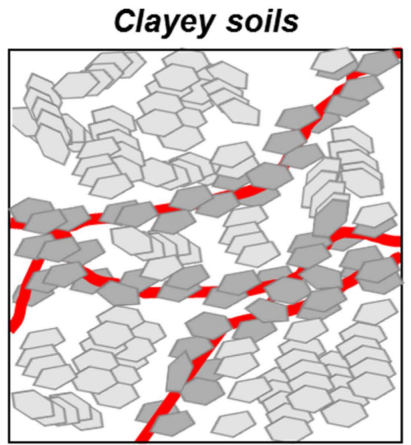

(c)

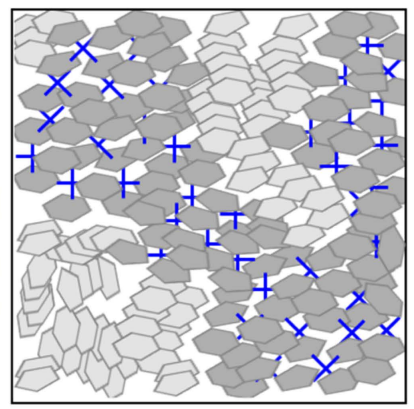

(d)

Figure 6. Schematic model for biopolymer treated soils: (a) chain type biopolymers with sandy soils; (b) gel type biopolymers with sandy soils; (c) chain type biopolymer with clayey soils; and (d) gel type biopolymers with clayey soils. 
Therefore, to employ biopolymers, specific in-situ characterization must be conducted in advance, to understand the particular composition of the targeted soil, such as its coarseness and clay ratio, which is important for determining the proper quantities of biopolymers and the best utilization methods for geotechnical engineering purposes. For instance, biopolymers have the potential to reduce aeolian erosion and promote vegetation growth in arid or semi-arid deserts [100]. Since desert soil mostly consists of coarse grains, biopolymers are expected to show suitable workability in terms of material rheology and soil structure. Moreover, additional clay-type materials or ionic chemicals (e.g., $\mathrm{Ca}^{2+}$ and $\mathrm{Mg}^{2+}$ ) can be applied to sandy soils to enhance the strengthening efficiency of biopolymers.

\subsection{Hydro-Dependency and Clogging Effect of Biopolymers}

When soils have increasing amounts of water, dehydrated biopolymer gels (Figure 6a,b) or biopolymer-clay matrices (Figure $6 \mathrm{c}, \mathrm{d}$ ) will adsorb and transfer water to hydrogels with a resulting volumetric expansion (i.e., swelling) [111,112]. The elastic properties of biopolymer hydrogels, such as their tensile strength and stiffness, diminish exponentially with increased water content [113], resulting in a remarkable reduction in soil strength, to approximately $1 / 10$ th of the strength of the dried state in a fully saturated condition. However, the unconfined compressive strength of re-wetted biopolymer soil mixtures (i.e., clayey soil $\geqslant 200 \mathrm{kPa}$; sandy soil $\geqslant 50 \mathrm{kPa}$ ) is much higher than that of untreated soils, and is immeasurable in most cases [106].

Furthermore, swelled viscous biopolymer hydrogels fill the pore spaces of soils (especially sand) and induce pore clogging, which reduces the hydraulic conductivity of soils by more than $3 \sim 4$ orders of magnitude [94,96,101]. Biopolymers thus have potential to be applied for hydraulic purposes in geotechnical engineering, such as in slurry walls, (temporary) seepage barriers, and grouting.

\section{Discussion}

\subsection{Opportunities for Biopolymers in Geotechnical Engineering}

Table 2 summarizes the features and engineering performance of biopolymer treatments and the other aforementioned engineered soil methods used in geotechnical engineering. Although OPC and geopolymers exhibit higher strengthening effects than biopolymer treatments, both OPC and geopolymers require huge amounts of binders $(10 \%-50 \%$ binder content to the weight of soil, in general), whereas biopolymers only require $0.5 \%-1.0 \%$ of binder content to achieve strength levels equivalent to those attained by massive cement mixing. Specifically, it has been reported that a $0.5 \%$ biopolymer mix is necessary to achieve strength levels that are equivalent to or even higher than those for $10 \%$ OPC-soil mixtures [98]. In addition, unlike other ground improvement methods, biopolymers work well in the presence of fine soils [103]. 
Table 2. Overview of ground improvement methods (after [7,72,98,103,114-117]).

\begin{tabular}{|c|c|c|c|c|c|c|}
\hline Properties & Cement & Chemicals & Geosynthetics & Geopolymer & MICP & Biopolymer \\
\hline $\begin{array}{l}\text { Soil } \\
\text { Competitiveness }\end{array}$ & $\begin{array}{l}\text { Course grained soils } \\
\text { Fine grained soils }\end{array}$ & Course grained soils & Course grained soils & $\begin{array}{l}\text { Course grained soils Fine } \\
\text { grained soils }\end{array}$ & Course grained soils & $\begin{array}{l}\text { Course grained to Fine } \\
\text { grained soils }\end{array}$ \\
\hline Method/Construction & $\begin{array}{l}\text { Deep mixing, injection, } \\
\text { grouting, direct } \\
\text { mixing spray }\end{array}$ & $\begin{array}{l}\text { Injection, grouting, } \\
\text { spray }\end{array}$ & In-situ installation & $\begin{array}{l}\text { Deep mixing, injection } \\
\text { grouting, direct } \\
\text { mixing Spray }\end{array}$ & $\begin{array}{l}\text { Direct microbe and } \\
\text { nutrient injection in } \\
\text { to ground }\end{array}$ & $\begin{array}{l}\text { Direct mixing, injection, } \\
\text { spraying exo-cultivated } \\
\text { biopolymers }\end{array}$ \\
\hline Main Materials & Cement Water & $\begin{array}{l}\text { Chemically synthesized } \\
\text { polymers }\end{array}$ & $\begin{array}{l}\text { Various synthesized } \\
\text { materials }\end{array}$ & $\begin{array}{l}\text { Pozzolanic materials, } \\
\text { water, cement }\end{array}$ & $\begin{array}{l}\text { Micro-organisms } \\
\text { urea, starch }\end{array}$ & Biopolymers, water \\
\hline Major Reactions & Hydration & $\begin{array}{l}\text { Solidification, chemical } \\
\text { bonding }\end{array}$ & Tensile reinforcement & Pozzolanic reactions & $\begin{array}{l}\text { Biological calcite } \\
\text { precipitation }\end{array}$ & $\begin{array}{l}\text { Hydrogen-/ionic- } \\
\text { bonding, gelation }\end{array}$ \\
\hline Advantages & $\begin{array}{l}\text { Strong, durable } \\
\text { Numerous case studies }\end{array}$ & $\begin{array}{l}\text { Strong, durable Quick } \\
\text { isolation Numerous } \\
\text { case studies }\end{array}$ & Quick, Easy to use & $\begin{array}{l}\text { Strong, durable Good } \\
\text { waste sink Lower carbon } \\
\text { footprint than cement }\end{array}$ & $\begin{array}{l}\text { No carbon footprint } \\
\text { Possible use with } \\
\text { material remediation }\end{array}$ & $\begin{array}{l}\text { Environment-friendly } \\
\text { Smaller concentrations } \\
\text { Stronger in fine soils }\end{array}$ \\
\hline $\begin{array}{l}\text { Disadvantages/ } \\
\text { Challenges }\end{array}$ & $\begin{array}{l}\text { Large carbon } \\
\text { footprint Disruption } \\
\text { of local ecosystem. } \\
\text { Disposal Problems }\end{array}$ & $\begin{array}{l}\text { High price } \\
\text { Environmental impacts. } \\
\text { Washout and } \\
\text { durability problems }\end{array}$ & $\begin{array}{l}\text { Heterogeneous } \\
\text { method Use limited } \\
\text { to shallow depths }\end{array}$ & $\begin{array}{l}\text { Similar environmental } \\
\text { problems as cement }\end{array}$ & $\begin{array}{l}\text { Ammonia byproduct } \\
\text { Limitations in } \\
\text { fine soils }\end{array}$ & $\begin{array}{l}\text { High price High } \\
\text { sensitivity (hydrophilic) } \\
\text { to presence of water }\end{array}$ \\
\hline $\begin{array}{l}\text { Compressive } \\
\text { Strength (MPa) } \\
\text { (average) }\end{array}$ & $2^{a}$ & $\begin{array}{l}0.8 \text { (acrylic } \\
\text { polymer-treated sand) }\end{array}$ & - & $10^{c}$ & 1.8 (shear strength) $\mathrm{d}$ & $4.3^{f}$ \\
\hline $\begin{array}{l}\text { Price for Soil } \\
\text { Treatment (average) }\end{array}$ & $45.5 \mathrm{USD} /$ ton $^{\mathrm{a}}$ & $200 \mathrm{USD} /$ ton $^{\mathrm{b}}$ & $2 \mathrm{USD} / \mathrm{m}^{2}$ & $30 \mathrm{USD} /$ ton $^{\mathrm{c}}$ & 90 USD $^{\text {e }}$ & $28^{g}-250^{f}$ USD/ton \\
\hline
\end{tabular}

${ }^{a}$ Compressive strength of cement mixed soil (10\% cement content to the weight of soil); ${ }^{\mathrm{b}}$ Acrylic grouting cost 4.4 times higher than cement treatment for the same $10 \%$ content to the soil mass (Anagnostopoulos and Hadjispyrou 2004); ${ }^{\mathrm{C}}$ Clay : fly-ash geopolymer $=100: 30$ mixing ratio in mass (Sukmak et al. 2013); ${ }^{\mathrm{d}}$ Microbial induced calcite precipitated sand;

${ }^{\mathrm{e}}$ Cost of $100 \mathrm{~L}$ of nutrient solution with $10 \mathrm{mM}$ urea $/ \mathrm{min}$ activity; ${ }^{\mathrm{f}} \beta$-glucan biopolymer $\left(0.5 \%\right.$ to the mass of soil) mixed residual soil; ${ }^{\mathrm{g}}$ Xanthan gum $(0.5 \%$ to the mass of soil) mixed. 
Moreover, biopolymers can be introduced into the soil by various practical modes of application including mixing, injection, spraying, and grouting, and they can be used for building materials, earth pavement, and farmland erosion prevention (Figure 7). Furthermore, biopolymers form a stable gel matrix inside soil that does not damage the local ecosystem. Combined with their water retaining properties in soil, biopolymers are thought to be capable of promoting vegetation growth.

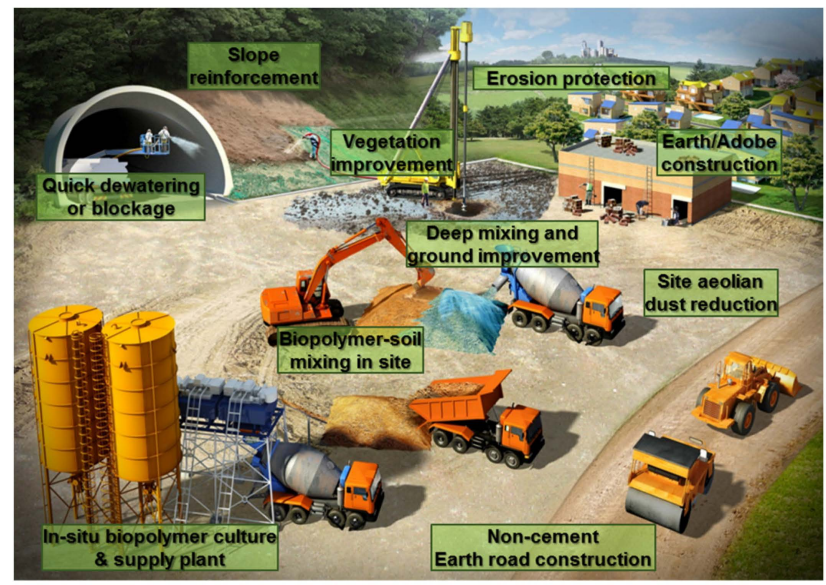

Figure 7. Schematic impression of biopolymer applications in geotechnical engineering practices in field.

The largest advantage of direct biopolymer implementation compared to other bio-soil methods is that biopolymers can be produced ex-situ (i.e., exo-cultivation) and applied in-situ with a higher degree of quality control, whereas MICP requires time-consuming in-situ cultivation. Moreover, biopolymers can be commercially mass produced, and react with soil particles immediately after mixing, which allows them to be utilized for temporary or rapid supporting purposes.

\subsection{Economic Feasibility of Biopolymers: Global market of Biopolymers}

Biopolymers are expected to be an effective, environment-friendly, and promising substitute to replace or reduce the use of OPC in soils for geotechnical engineering purposes. However, while biopolymers are effective at smaller concentrations compared to OPC, the current market price of biopolymers is significantly higher than that of OPC. The introduction of mass production and expanded utilization is expected to produce a significant cost reduction of biopolymers, as was the case with the considerable price reduction of xanthan gum following its commercialization (Figure 8).

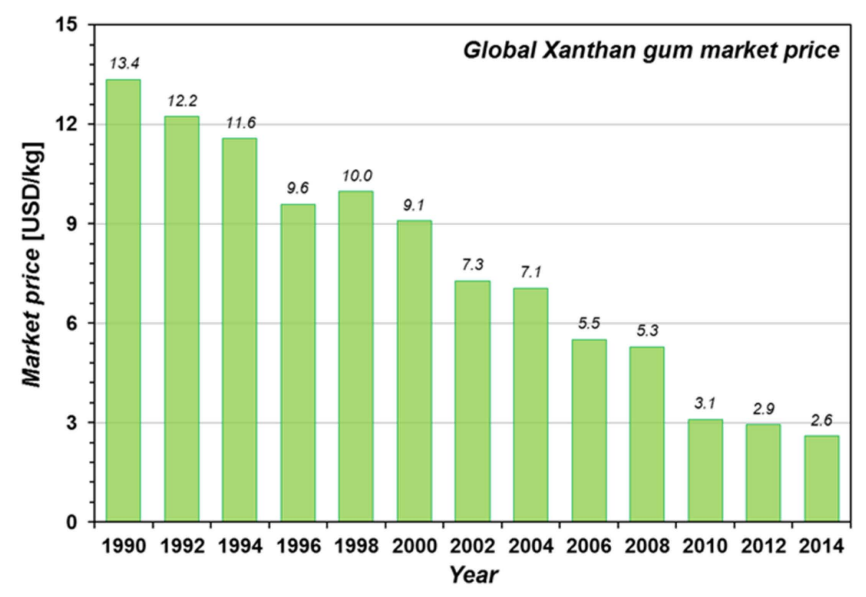

Figure 8. Global market price trend of xanthan gum. 
The material cost for $0.5 \%$ xanthan gum biopolymer for soil treatment has decreased from $\$ 250$ to $\$ 28$ during the last three decades.

While the majority of biopolymers are currently quite expensive, the actual cost of their use in geotechnical engineering largely depends on the choice of biopolymer. Additionally, the present market prices of most candidate biopolymers are for food grade quality with very high purity, and that standard results in significantly higher production cost. For geotechnical applications, edible grade purity is unnecessary, and thus the price of biopolymers can be reasonably expected to be lower when they are produced specifically for construction and geotechnical engineering applications.

\subsection{Biopolymer Competitiveness in Global Carbon Emission Trading}

Various raw materials are available for the production of biopolymers. For the first generation in the 1960s to the 1980s, edible biomass such as corn and sugarcane was widely used. Non-edible sources including food wastes and agricultural wastes were employed for the 2nd generation of biopolymer production in the 1990s. $\mathrm{CO}_{2}$ is now effectively being used as an alternative source in various biopolymer production strategies [118]. For instance, the production of xanthan gum is known to consume approximately $4.97 \mathrm{~kg}$ of $\mathrm{CO}_{2}$ for $1 \mathrm{~kg}$ of biopolymer $[119,120]$.

Meanwhile, cement production emits 1.25 tons of $\mathrm{CO}_{2}$ per 1 ton of cement, as a combined result of chemical reactions (52\%) and fossil fuel burning (48\%) during the calcination process [9] . For soil improvement in geotechnical engineering, treatment with a $0.5 \%$ ratio of xanthan gum to the weight of soil provides an equivalent or greater strengthening effect than that of a $10 \%$ cement mix [103]. However, for an equal unit ( 1 ton) of soil treatment, the material cost at current prices of employing xanthan gum becomes uneconomical compared to conventional cement mixing, being $37 \%$ more expensive (xanthan gum treatment: 13.5 USD/ton of soil; cement: $9.85 \mathrm{USD} /$ ton of soil), as shown in Table 3.

Table 3. Economic feasibility of biopolymer (xanthan gum) implementation in geotechnical engineering applications with environmental considerations.

\begin{tabular}{|c|c|c|}
\hline Soil Treatment Material & Cement & Xanthan Gum \\
\hline Market price of material & 98.5 USD/ton ${ }^{a}$ & $2,700 \mathrm{USD} /$ ton $^{\mathrm{b}}$ \\
\hline Required amount for 1 ton soil treatment $(\geqslant 2.5 \mathrm{MPa})$ & $100 \mathrm{~kg}(10 \%$ to soil 1 ton $)$ & $5 \mathrm{~kg}(0.5 \%$ to soil 1 ton $)$ \\
\hline Material price for 1 ton soil treatment & 9.85 USD & 13.50 USD \\
\hline $\mathrm{CO}_{2}$ emission per $1 \mathrm{~kg}$ material production $\left(\mathrm{kg} \mathrm{CO}_{2}\right)$ & +1.25 & -4.97 \\
\hline $\mathrm{CO}_{2}$ emission related to 1 ton soil treatment $\left(\mathrm{kg} \mathrm{CO}_{2}\right)$ & +125 & -24.85 \\
\hline $\mathrm{CO}_{2}$ emission trade related to 1 ton soil treatment ${ }^{\mathrm{c}}$ & +2.75 USD & $-0.55 \mathrm{USD}$ \\
\hline $\begin{array}{l}\text { Total cost for } 1 \text { ton soil treatment (with carbon trade } \\
\text { exchange considerations) }\end{array}$ & 12.50 USD & 12.95 USD \\
\hline
\end{tabular}

\footnotetext{
${ }^{a}$ Depicts the price of cement in the United States, in 2014 (www.statista.com); ${ }^{\text {b }}$ Depicts the average price of xanthan gum (market price: www.alibaba.com), in 2014; ${ }^{\mathrm{c}}$ EU ETS (European Union Emission Trading Scheme) carbon emission trade: $22 \mathrm{USD} /$ ton of $\mathrm{CO}_{2}$, in 2012.
}

With global greenhouse gas reduction efforts and carbon emission trading (considering a rate of $22 \mathrm{USD} /$ ton $\mathrm{CO}_{2}$ ) [121], the $\mathrm{CO}_{2}$ emission trade imposed on soil-cement mixtures (with $10 \%$ cement) has been estimated to be 2.75 USD, while $0.5 \%$ xanthan gum treatment would secure 0.55 USD CERs (Certified Emission Reductions) for 1 ton of soil treatment, respectively. When this $\mathrm{CO}_{2}$ emission trading is considered, in economic terms xanthan gum soil treatment becomes remarkably competitive, being only $3.6 \%$ more expensive than cement, as seen in Table 3 . Thus, especially when considering the aim of environment-friendly construction and development, biopolymers have high potential to replace high carbon emitting soil treatment materials. 


\subsection{Further Challenges for Practical Implementation of Biopolymer Technology}

In addition to the challenges related to market price, the use of biopolymers in soil engineering also raises concerns about durability. First, since biopolymers are organic materials, there are concerns about whether these biopolymers will biodegrade with time. Moreover, biopolymers are highly sensitive to the presence of water, and therefore durability concerns involving wetting and drying cycles, as well as overall soil strength in the presence of water, must be addressed. However, a recent study shows consistent strengthening performance of xanthan gum biopolymer-treated soils up to two years after mixing [103]. Thus, it is expected that the degradation characteristics of biopolymers would be acceptable when they are used for temporary or short-term practices. They would also be advantageous in certain applications because they would make further remediation processes or removal unnecessary, since the biopolymers are expected to naturally decompose with time.

To address other durability concerns, various types of biopolymers and/or practical implementation methods can be utilized together to improve the overall quality and reliability of biopolymer treated soils. Because most biopolymers exhibit high sensitivity to water, viable methods for increasing the effectiveness of biopolymer treated soils in water will greatly improve the reliability of these soils for ground improvement and stabilization. Several methods have been studied and conceived to resolve this issue, such as the use of biopolymers with thermo-gelation properties. As previously noted, gellan gum and agar gum are among the biopolymers that possess such thermo-gelation properties. These biopolymers become highly soluble in water at around $85-90^{\circ} \mathrm{C}$, and hardening of the gel solution occurs as the gel is cooled to room temperature $[108,109]$. Such thermo-gelating biopolymers retain considerable strength even when subjected to water.

Another plausible solution is the use of protein based biopolymers. Protein based biopolymers, such as casein proteins, have been employed in a wide variety of fields such as in the manufacturing of adhesives. Since such proteins have lower hydrophilic properties than their polysaccharide biopolymer counterparts, soils that are stabilized by such proteins may provide higher resistance to water. A recent study showed that $6 \%$ casein mixed with lime and loam was suitable for use in ceramic manufacturing [122].

In addition to these methods, the use of cross-linking for biopolymers may provide a more powerful soil stabilizing method. Cross-linking is a technique used to greatly improve the properties of a specific material by introducing an agent that promotes interactions between separate polymer chains, thereby enhancing their overall strength. One common application of cross-linking is the use of sulfur in rubber polymer to greatly enhance the strength and stiffness of the rubber, a process also known as vulcanization [123]. Cross-linking has also been used to enhance the properties of gel solutions. A double network hydrogel composed of two different biopolymers with a cross-linking agent was used to create a hydrogel with high mechanical strength. The resulting hydrogels showed extremely high strength and durability, and one case study showed that the hydrogel, which could easily be sliced at $0.2 \mathrm{MPa}$ prior to cross-linking, exhibited a strength of $25 \mathrm{MPa}$ at a strain of over $80 \%$ after cross-linking [124,125].

Overall, a wide variety of methods can be applied to improve the mechanical properties of biopolymer treated soils, and as such, the use of biopolymers is emerging as a possible eco-friendly, sustainable method for soil improvement and stabilization. However, various further studies focusing on practical implementation methods and the development of suitable equipment are required to ensure desired construction performance and reliability of biopolymer applications for in situ geotechnical engineering purposes.

\section{Conclusions}

Ground enhancement methods have been intensively studied and developed over centuries. The use of cement in geotechnical engineering could be considered the beginning of modern ground enhancement methods, and numerous studies have since been performed to enhance the properties of cement. However, in the late 20th century, environmental concerns gave rise to increasing demand for 
environment-friendly construction methods. The development of green cement and several possible cement substitutes, including the direct use of biopolymers in the soil layer, have been proposed.

Recent studies have shown that biopolymers can strengthen soils, and they offer several advantages in such applications, including being environment-friendly and effective at low concentrations. Several studies have shown that the strengthening induced by biopolymer treatment is maximized in the presence of fines, especially clay particles. For polysaccharide-type biopolymers, hydroxyl groups on the polymer surfaces induce hydrogen bonding with water molecules, making them hydrophilic, and enabling the formation of firm (i.e., viscous) hydrocolloids or hydrogels.

Meanwhile, when water is scarce, as in conditions of drought or dry soils, biopolymers can form direct hydrogen bonds with clay particles, or indirect ionic bonds with these particles, in the presence of intermediate ions such as alkali- or alkali earth- metal ions in the soil. Direct and indirect bonding leads to the formation of a firm biopolymer-clay matrix, which provides a significant increase in soil cohesion. Proper mixing of coarse particles, clay particles, and biopolymers is thus expected to provide optimal strengthening effects, due to the combination of increased mechanical friction between coarse particles, and a cementation effect between biopolymer-clay matrices.

In contrast to cement, biopolymers have strong potential to reduce carbon dioxide emissions. Moreover, some biopolymers show functionality to support vegetation growth and stabilization, which can be applied as countermeasures for farmland preservation and anti-desertification and against other threats to environmental conservation.

Although their benefits are numerous, several challenges related to the use of biopolymers remain to be addressed, including sensitivity to water, market costs, and possible biological degradation. Overall, given the wide variety of available biopolymers, the flexibility of their modification, and the numerous advantageous properties that they possess, the use of biopolymers in geotechnical engineering appears to have a promising future.

Acknowledgments: The research described in this paper was financially supported by a National Research Foundation of Korea (NRF) grant funded by the Korean government (MSIP) (No. 2015R1A2A2A03006268), by a grant from the Strategic Research Project (Development of Key Excavation Solutions for Expandable Urban Underground Space) funded by the Korea Institute of Civil Engineering and Building Technology (KICT), and by the KAIST End-Run Program (No. N01150661) supported by the Korea Ministry of Science, ICT and Future Planning (MISP). The second author is supported by the "U-City Master and Doctor Course Grant (Education) Program" under the Korea Ministry of Land, Infrastructure and Transport (MOLIT).

Author Contributions: Ilhan Chang and Gye-Chun Cho conceived and constructed the outline and context of the review. Ilhan Chang and Jooyoung Im provided detailed reviews on previous studies and analyzed the data. All authors wrote the paper together with different contributions (Jooyoung Im was responsible for Sections 2-4; Ilhan Chang contributed to Sections 5 and 6; and Gye-Chun Cho provided an overall summary in Sections 1 and 6).

Conflicts of Interest: The authors declare no conflict of interest.

\section{References}

1. Potts, D.T. Mesopotamian Civilization: The Material Foundations; Cornell University Press: Ithaca, NY, USA, 1997; p. 366.

2. Kemp, B.J. Ancient Egypt: Anatomy of a Civilization; Routledge: London, UK, 1989; p. 437.

3. Yang, F.; Zhang, B.; Ma, Q. Study of Sticky Rice-Lime Mortar Technology for the Restoration of Historical Masonry Construction. Acc. Chem. Res. 2010, 43, 936-944. [CrossRef] [PubMed]

4. Delatte, N.J. Lessons from Roman Cement and Concrete. J. Prof. Issues Eng. Deucation Pract. 2001, 127, 109-115. [CrossRef]

5. Sherwood, P.T. Soil Stabilization with Cement and Lime; HMSO: London, UK, 1993.

6. Hargreaves, D. The Global Cement Report 10th Edition; International Cement Review: Surrey, UK, 2013.

7. Maclaren, D.C.; White, M.A. Cement: Its Chemistry and Properties. J. Cemical Educ. 2003, 80, 623. [CrossRef]

8. Larson, A. Sustainability, Innovation, and Entrepreneurship; University of Virginia: Charlottesville, VA, USA, 2011. 
9. Worrell, E.; Price, L.; Martin, N.; Hendriks, C.; Meida, L.O. Carbon Dioxide Emissions from the Global Cement Industry. Ann. Rev. Energy Environ. 2001, 26, 303-329. [CrossRef]

10. Metz, B.; Davidson, O.; Coninck, H.D.; Loos, M.; Meyer, L. Carbon Dioxide Capture and Storage; Intergovernmental Panel on Climate Change: New York, NY, USA, 2005.

11. Oss, H.G.V. Cement Statistics and Information; US Geological Survey: Reston, VA, USA, 2014.

12. Rapier, R. Global Carbon Dioxide Emissions - Facts and Figures; Consumer Energy Repor, 2012.

13. Plank, J. Applications of biopolymers in construction engineering. In Biopolymers Online; Wiley-VCH Verlag GmbH \& Co. KGaA: Weinheim, Germany, 2005.

14. U.S. Energy Information Administration. International Energy Statistics; U.S. Department of Energy: Washington, DC, USA, 2015.

15. Taylor, H.F.W. Cement Chemistry; Thomas Telford Publishing: London, UK, 1997.

16. Hansen, P.J. Effect of high $\mathrm{pH}$ on the growth and survival of marine phytoplankton: Implications for species succession. Aquat. Microb. Ecol. 2002, 28, 279-288. [CrossRef]

17. Rao, A.; Jha, K.N.; Misra, S. Use of aggregates from recycled construction and demolition waste in concrete. Resour. Conserv. Recycl. 2007, 50, 71-81. [CrossRef]

18. Water Environment Federation. Urban Runoff Quality Manaement; Water Environment Federation: Alexandria, VA, USA, 1998.

19. Parliamentary Office of Science and Technology. Urban Flooding; Postnote: London, UK, 2007.

20. Burton, G.A.; Pitt, R. Stormwater Effects Handbook: A Toolbox for Watershed Managers, Scientists, and Engineers; Lewis Publishers: Boca Raton, FL, USA, 2002.

21. Schueler, T.R. Watershed Protection Techniques: A Quarterly Bulletin on Urban Watershed Restoration and Protection Tools; Center for Watershed Restoration: Silver Spring, MD, USA, 1994.

22. Solecki, W.D.; Rosenzweig, C.; Parshall, L.; Pope, G.; Clark, M.; Cox, J.; Wiencke, M. Mitigation of the heat island effect in urban New Jersey. Glob. Environ. Chang. B Environ. Hazards 2005, 6, 39-49. [CrossRef]

23. Regents, A.B.O. Urban Climate_Climate Study and UHI via the Internet Wayback Machine; Arizona State University: Tempe, AZ, USA, 2006.

24. Arnfield, A.J. Two decades of urban climate research: A review of turbulence, exchanges of energy and water, and the urban heat island. Int. J. Climatol. 2003, 23, 1-26. [CrossRef]

25. Kurn, D.; Bretz, S.; Huang, B.; Akbari, H. The Potential for Reducting Urban Air Temperatures and Energy Consumption through Vegetative cooling. In ACEEE Summer Study on Energy Efficiency in Buildings; American Council for an Energy Efficient Economy: Pacific Grove, CA, USA, 1994.

26. McPherson, E.G.; Simpson, J.R.; Peper, P.J.; Maco, S.E.; Xiao, Q. Municipal forest benefits and costs in five US cities. J. For. 2005, 103, 411-416.

27. Torring, M. Management of concrete demolition waste. In Concrete Technology for a Sustainable Development in the 21st Century; CRC Press: Boca Raton, FL, USA, 2000; pp. 321-331.

28. Meijer, E.; Kromhout, H.; Heederik, D. Respiratory effects of exposure to low levels of concrete dust containing crystalline silica. Am. J. Ind. Med. 2001, 40, 133-140. [CrossRef] [PubMed]

29. Gotoh, T.; Nishimura, T.; Nakata, M.; Nakaguchi, Y.; Hiraki, K. Air Pollution by Concrete Dust from the Great Hanshin Earthquake. J. Environ. Qual. 2002, 31, 718-723. [CrossRef] [PubMed]

30. Basu, D.; Misra, A. Sustainability in Geotechnical Engineering. In Proceedings of the 18th International Conference on Soil Mechanics and Geotechnical Engineering, Paris, France, 2-6 September 2013.

31. Barrett, R.J. Use of Plastic Filters in Coastal Structures. In Proceedings of the 16th International Conference on Coastal Engineers, Tokyo, Japan, September 1966; pp. 1048-1067.

32. Ward, I.M. The Orientation of Polymers to Produce high Performance Materials. In Proceedings of the Symposium on Polymer Grid Reinforcement in Civil Engineering, London, UK, 22-23 March 1984.

33. Eith, A.W.; Koerner, R.M. Field Evaluation of GEonet Flow Rate (Transmissivity) Under Increasing Load. J. Geotext. Geomembr. 1992, 11, 153-166. [CrossRef]

34. Narjary, B.; Aggarwal, P.; Singh, A.; Chakraborty, D.; Singh, R. Water availability in different soils in relation to hydrogel application. Geoderma 2012, 187-188, 94-101. [CrossRef]

35. Kulicke, W.M.; Kniewske, R.; Klein, J. Preparation, characterization, solution properties and rheological behaviour of polyacrylamide. Prog. Polym. Sci. 1982, 8, 373-468. [CrossRef]

36. Malik, M.; Letey, J. Adsorption of Polyacrylamide and Polysaccharide Polymers on Soil Materials. Soil Sci. Soc. Am. J. 1991, 55, 380-383. [CrossRef] 
37. Laird, D.A. Bonding Between Polyacrylamide and Clay Mineral Surfaces. Soil Sci. 1997, 162, 826-832. [CrossRef]

38. Fox, D.; Bryan, R.B. Influence of a polyacrylamide soil conditioner on runoff generation and soil erosion: Field tests in Baringo District, Kenya. Soil Technol. 1992, 5, 101-119. [CrossRef]

39. Orts, W.J.; Roa-Espinosa, A.; Sojka, R.E.; Glenn, G.M.; Imam, S.H.; Erlacher, K.; Pedersen, J.S. Use of synthetic polymers and biopolymers for soil stabilization in agricultural, construction, and military applications. J. Mater. Civ. Eng. 2007, 19, 58-66. [CrossRef]

40. Karol, R.H. Chemical Grouting and Soil Stabilization, 3rd ed.; CRC Press: New York, NY, USA, 2003.

41. Burnotte, F.; Lefebvre, G.; Grondin, G. A case record of electroosmotic consolidation of soft clay with improved soilelectrode contact. Can. Geotech. J. 2004, 41, 1038-1053. [CrossRef]

42. Lefebvre, G.; Burnotte, F. Improvements of electroosmotic consolidation of soft clays by minimizing power loss at electrodes. Can. Geotech. J. 2002, 39, 399-408. [CrossRef]

43. Ou, C.Y.; Chien, S.C.; Chang, H.H. Soil improvement using electroosmosis with the injection of chemical solutions: Field tests. Can. Geotech. J. 2009, 46, 727-733. [CrossRef]

44. Duxon, P.; Jimenez, A.F.; Provis, J.L.; Lukey, G.C.; Palomo, A.; Deventer, J.S.J.V. Geopolymer technology: The current state of the art. J. Mater. Sci. 2007, 42, 2917-2933. [CrossRef]

45. Kim, D.; Lai, H.T.; Chilingar, G.V.; Yen, T.F. Geopolymer formation and its unique properties. Environ. Geol. 2006, 51, 103-111. [CrossRef]

46. Hench, L.L. Sol-Gel Silica. Properties, Processing and Technology Transfer; Noyes Publications: Park Ridge, NJ, USA, 1998.

47. Rovnaník, P. Effect of curing temperature on the development of hard structure of metakaolin-based geopolymer. Constr. Build. Mater. 2010, 24, 1176-1183. [CrossRef]

48. Van Jaarsveld, J.G.S.; van Deventer, J.S.J.; Lukey, G.C. The effect of composition and temperature on the properties of fly ash- and kaolinite-based geopolymers. Chem. Eng. J. 2002, 89, 63-73. [CrossRef]

49. Bakharev, T. Resistance of geopolymer materials to acid attack. Cem. Concr. Rese. 2005, 35, 658-670. [CrossRef]

50. Sigel, A.; Sigel, H.; Sigel, R.K.O. Biomineralization: From Nature to Application; Wiley: Hoboken, NJ, USA, 2008; Volume 4.

51. Lear, G.; Lewis, G.D. Microbial Biofilms: Current Research and Applications; Caister Academic Press: Norwich, UK, 2012.

52. DeJong, J.; Fritzges, M.; Nüsslein, K. Microbially Induced Cementation to Control Sand Response to Undrained Shear. J. Geotech. Geoenviron. Eng. 2006, 132, 1381-1392.

53. Whiffin, V.S.; van Paassen, L.A.; Harkes, M.P. Microbial Carbonate Precipitation as a Soil Improvement Technique. Geomicrobiol. J. 2007, 24, 417-423. [CrossRef]

54. Stockes-Fischer, S.; Galinat, J.K.; Ban, S.S. Microbiological precipitation of CaCO3. Soil Biol. Biochem. 1999, 31, 1563-1571. [CrossRef]

55. Fujita, Y.; Ferris, F.G.; Lawson, R.D.; Colwell, F.S.; Smith, R.W. Calcium Carbonate Precipitation by Ureolytic Subsurface Bacteria. Geomicrobiol. J. 2000, 17, 305-318. [CrossRef]

56. Mortensen, B.M.; Haber, M.J.; DeJong, J.T.; Caslake, L.G.; Nelson, D.C. Effects of environmental factors on microbial induced calcium carbonate precipitation. J. Appl. Microbiol. 2011, 111, 338-349. [CrossRef] [PubMed]

57. DeJong, J.T.; Mortensen, B.M.; Martinez, B.C.; Nelson, D.C. Bio-mediated soil improvement. Ecol. Eng. 2010, 36, 197-210. [CrossRef]

58. Neupane, D.; Yasuhara, H.; Kinoshita, N.; Unno, T. Applicability of Enzymatic Calcium Carbonate Precipitation as a Soil-Strengthening Technique. J. Geotech. Geoenviron. Eng. 2013, 139, 2201-2211. [CrossRef]

59. Fujita, Y.; Taylor, J.L.; Gresham, T.L.; Delwiche, M.E.; Colwell, F.S.; Mcling, T.L.; Mcling, L.M.; Petzke, L.M.; Smith, R.W. Stimulation of microbial urea hydrolysis in groundwater to enhance calcite precipitation. Environ. Sci. Technol. 2008, 42, 3025-3032. [CrossRef] [PubMed]

60. Renforth, R.; Manning, D.A.C.; Lopez-Capel, E. Carbonate precipitation in artificial soils as a sink for atmospheric carbon dioxide. Appl. Geochem. 2009, 24, 1757-1764. [CrossRef]

61. Ramakrishnan, V.; Bang, S.S.; Deo, K.S. A novel technique for repairing cracks in high performance concrete using bacteria. In Proceedings of the International Conference on High Performance High Strength Concrete, Perth, Australia, 10-12 August 1998; Curtin University of Technology: Perth, Australia, 1998; pp. 597-618. 
62. Ramachandran, S.K.; Ramakrishnan, V.; Band, S.S. Remediation of concrete using micro-organisms. ACI Mater. J. 2001, 98, 3-9.

63. Rong, H.; Qian, C.; Wang, R. A cementation method of loose particles based on microbe-based cement. Sci. China Technol. Sci. 2011, 54, 1722-1729. [CrossRef]

64. Yasuhara, H.; Neupane, D.; Hayashi, K.; Okamura, M. Experiments and predictions of physical properties of sand cemented by enzymatically-induced carbonate precipitation. Soils Found. 2012, 52, 539-549. [CrossRef]

65. Pham, V.; Paassen, L.V.; Nakano, A.; Kanayama, M.; Heimovaara, T. Microbially induced carbonate precipitation (MICP) by denitrification as ground improvement method-Process control in sand column experiments. In Paper presented at the EGU General Assembly 2013, Vienna, Austria, 7-12 April 2013.

66. FuWei, Y.; BingJian, Z.; ChangChu, P.; YuYao, Z. Traditional mortar represented by sticky rice lime mortar-One of the great inventions in ancient China. Sci. China Ser. E Technol. Sci. 2009, 52, 1641-1647.

67. US National Library of Medicine. Medical Subject Headings (Polynucleotides). Available online: http://www.nlm.nih.gov/mesh/2011/mesh_browser/MBrowser.html (accessed on 31 August 2011).

68. Kalia, S.; Averous, L. Biopolymers: Biomedical and Environmental Applications; Wiley: Hoboken, NJ, USA, 2011.

69. Belitz, H.D.; Grosch, W.; Schieberle, P. Food Chemistry, 4th revised and extended edition ed.; Springer: Leipzig, Germany, 2009.

70. Saha, D.; Bhattacharya, S. Hydrocolloids as thickening and gelling agents in food: A critical review. J. Food Sci. Technol. 2010, 47, 587-597. [CrossRef] [PubMed]

71. Lorenzo, G.; Zaritzky, N.; Califano, A. Rheological analysis of emulsion-filled gels based on high acyl gellan gum. Food Hydrocoll. 2012, 30, 672-680. [CrossRef]

72. Velde, K.V.D.; Kiekens, P. Biopolymers: Overview of several properties and consequences on their applications. Polym. Test. 2002, 21, 433-442. [CrossRef]

73. Cole, D.; Ringelberg, D.; Reynolds, C. Small-scale mechanical properties of biopolymers. J. Geotech. Geoenviron. Eng. 2012, 138, 1063-1074. [CrossRef]

74. De Muynck, W.; de Belie, N.; Verstraete, W. Microbial carbonate precipitation in construction materials: A review. Ecol. Eng. 2010, 36, 118-136. [CrossRef]

75. Adibkia, K.; MR, S.S.; Nokhodchi, A.; Javadzedeh, A.; Barzegar-Jalali, M.; Barar, J.; Mohammadi, G.; Omidi, Y. Piroxicam nanoparticles for ocular delivery: Physicochemical characterization and implementation in endotoxin-induced uveitis. J. Drug Target. 2007, 15, 407-416. [CrossRef] [PubMed]

76. Barrére, G.C.; Barber, C.E.; Daniels, M.J. Molecular cloning of genes involved in the production of the extracellular polysaccharide xanthan by Xanthomonas campestris pv. campestris. Int. J. Biol. Macromol. 1986, 8, 372-374. [CrossRef]

77. Chang, Y.J.; Lee, S.; Yoo, M.A.; Lee, H.G. Structural and biological characterization of sulfated-derivatized oat $\beta$-glucan. J. Agric. Food Chem. 2006, 54, 3815-3818. [CrossRef] [PubMed]

78. Daniel, J.; Whistler, R.L.; Voragen, A.C.J.; Pilnik, W. Starch and other polysaccharides. In Ullmann's Encyclopedia of Industrial Chemistry; VCH Verlagsgesellschaft mbH: Weinheim, Germany, 1994; Volume A25.

79. Harada, T.; Misaki, A.; Saito, H. Curdlan: A bacterial gel-forming $\beta-1,3$-glucan. Arch. Biochem. Biophys. 1968, 124, 292-298. [CrossRef]

80. Hassan, H.; Al-Oraimi, S.; Taha, R. Evaluation of open-graded friction course mixtures containing cellulose fibers and styrene butadiene rubber polymer. J. Mater. Civ. Eng. 2005, 17, 416-422. [CrossRef]

81. Wan, M.W.; Petrisor, I.G.; Lai, H.T.; Kim, D.; Yen, T.F. Copper adsorption through chitosan immobilized on sand to demonstrate the feasibility for in situ soil decontamination. Carbohydr. Polym. 2004, 55, 249-254. [CrossRef]

82. Fahnestock, K.J.; Austero, M.S.; Schauer, C.L. Natural Polysaccharides: From Membranes to Active Food Packaging. In Biopolymers: Biomedical and Environmental Applications; Wiley: Hoboken, NJ, USA, 2011.

83. Maher, M.; Ho, Y. Mechanical Properties of Kaolinite/Fiber Soil Composite. J. Geotech. Eng. 1994, 120, 1381-1393. [CrossRef]

84. Sivakumar Babu, G.; Vasudevan, A. Strength and Stiffness Response of Coir Fiber-Reinforced Tropical Soil. J. Mater. Civ. Eng. 2008, 20, 571-577. [CrossRef]

85. Annabi, M.; Houot, S.; Francou, C.; Poitrenaud, M.; Bissonnais, Y.L. Soil Aggregate Stability Improvement with Urban Composts of Different Maturities. Soil Sci. Soc. Am. J. 2007, 71, 413-423. [CrossRef]

86. Zobel, H.F. Molecules to granules: A comprehensive starch review. Starch 1988, 40, 1. [CrossRef] 
87. Food and Agriculture Organization of the United Nations. FAO Statistical Yearbook 2009; FAO Economic and Social Development Department, Ed.; FAO: Rome, Italy, 2009.

88. Francis, H.P.; DeBoer, E.D.; Wermers, V.L. High Temperature Drilling Fluid Component. U.S. Patent 4,652,384, 24 March 1987.

89. Jose, A.; Carvalho, F. Starch as Source of Polymeric Materials. In Biopolymers: Biomedical and Environmental Applications; Wiley: Salem, MA, USA, 2011.

90. Sahoo, D.; Nayak, P.L. Chitosan: The Most Valuable Derivative of Chitin. In Biopolymers: Biomedical and Environmental Applications; Wiley: Hoboken, NJ, USA, 2011.

91. Nascimento, T.; Rego, C.; Oliveira, H. Potential use of chitosan in the control of grapevine trunk diseases. Phytopathol. Mediterr. 2007, 46, 218-224.

92. Cheung, W.H.; Ng, J.C.Y.; McKay, G. Kinetic analysis of the sorption of copper(II) ions on chitosan. J. Chem. Technol. Biotechnol. 2003, 78, 562-571. [CrossRef]

93. Renault, F.; Sancey, B.; Badot, P.M.; Crini, G. Chitosan for coagulation/flocculation processes-An eco-friendly approach. Eur. Polym. J. 2009, 45, 1337-1348. [CrossRef]

94. Khachatoorian, R.; Petrisor, I.G.; Kwan, C.C.; Yen, T.F. Biopolymer plugging effect: Laboratory-pressurized pumping flow studies. J. Petroleum Sci. Eng. 2003, 38, 13-21. [CrossRef]

95. McIntosh, M.; Ston, B.A.; Stanisich, V.A. Curdlan and other bacterial (1 $\rightarrow 3$ )-[beta]-D-glucans. Appl. Microbiol. Biotechnol. 2005, 68, 163-173. [CrossRef] [PubMed]

96. Ivanov, V.; Chu, J. Applications of microorganisms to geotechnical engineering for bioclogging and biocementation of soil in situ. Rev. Environ. Sci. Biotechnol. 2008, 7, 139-153. [CrossRef]

97. Bacic, A.; Fincher, G.B.; Stone, B.A. Chemistry Biochemistry and Biology of (1-3)-[beta]-glucans and Related Polysaccharides, 1st ed.; Academic Press: Amsterdam, The Netherlands, 2009.

98. Chang, I.; Cho, G.C. Strengthening of Korean residual soil with $\beta-1,3 / 1,6$-glucan biopolymer. Constr. Build. Mater. 2012, 30, 30-35. [CrossRef]

99. Chang, I.; Cho, G.C. Geotechnical behavior of a beta-1,3/1,6-glucan biopolymer-treated residual soil. Geomech. Eng. 2014, 7, 633-647. [CrossRef]

100. Chang, I.; Prasidhi, A.K.; Im, J.; Shin, H.D.; Cho, G.C. Soil treatment using microbial biopolymers for anti-desertification purposes. Geoderma 2015, 253-254, 39-47. [CrossRef]

101. Bouazza, A.; Gates, W.P.; Ranhith, P.G. Hydraulic conductivity of biopolymer-treated silty sand. Geotechnique 2009, 59, 71-72. [CrossRef]

102. Nugent, R.A.; Zhang, G.; Gambrell, R.P. Effect of exopolymers on the liquid limit of clays and its engineering implications. Transp. Res. Rec. J. Transp. Res. Board 2009, 2101, 34-43. [CrossRef]

103. Chang, I.; Im, J.; Prasidhi, A.K.; Cho, G.C. Effects of Xanthan gum biopolymer on soil strengthening. Constr. Build. Mater. 2015, 74, 65-72. [CrossRef]

104. McHugh, D.J. A Guide to the Seaweed Industry; Food and Agriculture Organization of The United Nations: Rome, Italy, 2003.

105. Khatami, H.; O'Kelly, B. Improving mechanical properties of sand using biopolymers. J. Geotech. Geoenviron. Eng. 2012, 139, 1402-1406. [CrossRef]

106. Chang, I.; Prasidhi, A.K.; Im, J.; Cho, G.C. Soil strengthening using thermo-gelation biopolymers. Constr. Build. Mater. 2015, 77, 430-438. [CrossRef]

107. Imeson, A. Food Stabilisers, Thickeners and Gelling Agents; Wiley-Blackwell Publishing: Chichester, UK, $2009 ;$ p. 368.

108. Huang, M.; Kennedy, J.F.; Li, B.; Xu, X.; Xie, B.J. Characters of rice starch gel modified by gellan, carrageenan, and glucomannan: A texture profile analysis study. Carbohydr. Polym. 2007, 69, 411-418. [CrossRef]

109. Tang, J.; Tung, M.A.; Zeng, Y. Gelling Properties of Gellan Solutions Containing Monovalent and Divalent Cations. J. Food Sci. 1997, 62, 688-692. [CrossRef]

110. Ferruzzi, G.G.; Pan, N.; Casey, W.H. Mechanical properties of gellan and polyacrlamide gels with implications for soil stabilization. Soil Sci. 2000, 165, 778-792. [CrossRef]

111. Chang, C.; Duan, B.; Cai, J.; Zhang, L. Superabsorbent hydrogels based on cellulose for smart swelling and controllable delivery. Eur. Polym. J. 2010, 46, 92-100. [CrossRef]

112. Bueno, V.B.; Bentini, R.; Catalani, L.H.; Petri, D.F.S. Synthesis and swelling behavior of xanthan-based hydrogels. Carbohydr. Polym. 2013, 92, 1091-1099. [CrossRef] [PubMed] 
113. Yakimets, I.; Paes, S.S.; Wellner, N.; Smith, A.C.; Wilson, R.H.; Mitchell, J.R. Effect of Water Content on the Structural Reorganization and Elastic Properties of Biopolymer Films: A Comparative Study. Biomacromolecules 2007, 8, 1710-1722. [CrossRef] [PubMed]

114. Davidovits, J. Geopolymer Chemistry and Applications; Geopolymer Institute: Saint-Quentin, France, 2008; p. 585.

115. DeJong, J.T.; Fritzges, M.B.; Nusslein, K. Microbially Induced Cementation to Control Sand Response to Undrained Shear. J. Geotech. Geoenviron. Eng. 2006, 132, 1381-1392. [CrossRef]

116. Koerner, R.M. Designing With Geosynthetics, 6th ed.; Xlibris Publishers: Dartford, UK, 2012; p. 914.

117. Oh, J.E.; Monteiro, P.J.M.; Jun, S.S.; Choi, S.; Clark, S.M. The evolution of strength and crystalline phases for alkali-activated ground blast furnace slag and fly ash-based geopolymers. Cem. Concr. Res. 2010, 40, 189-196. [CrossRef]

118. Niaounakis, M. Biopolymers: Reuse, Recycling, And Disposal, 1st ed.; Elsevier/WA: Oxford, UK; Waltham, MA, USA, 2013; p. 432.

119. Mohanty, A.K.; Misra, M.; Drzal, L.T. Sustainable Bio-Composites from Renewable Resources: Opportunities and Challenges in the Green Materials World. J. Polym. Environ. 2002, 10, 19-26. [CrossRef]

120. Krishna Leela, J.; Sharma, G. Studies on xanthan production from Xanthomonas campestris. Bioprocess Eng. 2000, 23, 687-689. [CrossRef]

121. Guerrero-Lemus, R.; Martinez-Duart, J.M. Renewable energies and $\mathrm{CO}_{2}$ : Cost Analysis, Environmental Impacts and Technological Trends, 2012 ed.; Springer: London, UK; New York, NY, USA, 2013; p. 373.

122. Minke, G. Building with earth-30 years of research and development at the University of Kassel. In Proceedings of the International Symposium on Earthen Structures, Bangalore, Bangalore, India, 22-24 August 2007; Interline Publishing: Karnataka, India, 2007.

123. Mark, J.E.; Erman, B.; Eirich, F.R. Science and Technology of Rubber; Academic Press: San Diego, CA, USA, 1994.

124. Gong, J.P.; Katsuyama, Y.; Kurokawa, T.; Osada, Y. Double-Network Hydrogels with Extremely High Mechanical Strength. Adv. Mater. 2003, 15, 1155-1158. [CrossRef]

125. Nakayama, A.; Kakugo, A.; Gong, J.P.; Osada, Y.; Takai, M.; Erata, T.; Kawano, S. High Mechanical Strength Double-Network Hydrogel with Bacterial Cellulose. Adv. Funct. Mater. 2004, 14, 1124-1128. [CrossRef]

(C) 2016 by the authors; licensee MDPI, Basel, Switzerland. This article is an open access article distributed under the terms and conditions of the Creative Commons by Attribution (CC-BY) license (http://creativecommons.org/licenses/by/4.0/). 